\title{
Review of Tom Ginsburg and Aziz Huq, How to Save a Constitutional Democracy, The University of Chicago Press, 2018 ${ }^{* *}$
}

\section{INTRODUCTION}

Comparative constitutional scholars Tom Ginsburg and Aziz Huq have written an impressive book, called How to Save a Constitutional Democracy. Their work, which has recently been awarded the 2019 ICON-S Book Prize, appeared together with many other books and articles dealing with the same phenomenon, namely that of "democratic erosion" (Dixon 2018). How to Save... constitutes the most complete, elaborate and sophisticated expression of all this emerging literature (BERMEO 2016; GRABER et al. 2018; LANDAU 2013; Levitsky \& Ziblatt 2018; Luo \& Przeworski 2019; Sunstein 2018).

Ginsburg and Huq clearly succeed in their project: their book is genuinely comparative (they make an explicit effort trying not to fall in the trap of "American exceptionalism"), and it is written in a way that reveals a fine knowledge of history, a critical approach to political theory, and a non-naïve understanding of how contemporary politics actually works. ${ }^{1}$

In the first part of their book, Ginsburg and Huq distinguish between "authoritarian collapse", which they present as "a rapid, wholesale turn away from democracy," and "democratic erosion", which they describe as

Doctor of Law from the University of Buenos Aires (UBA) and Doctor of Jurisprudence from the University of Chicago. He also did a postdoctoral degree at Balliol College (Oxford University). And he was awarded doctoral honoris causa at the University of Valparaiso this year.

Para citar la reseña: Gargarella, R. Review of Tom Ginzburg and Aziz Huq, 'How to Save a Constitutional Democracy', The University of Chicago Press, 2018. En Revista Derecho del Estado, Universidad Externado de Colombia. N. ${ }^{\circ}$ 44, septiembre-diciembre de 2019 , pp. 397-406.

DOI: https://doi.org/10.18601/01229893.n44.15

1 In fact, Ginsburg and Huq tend to be quite critical of the American practice. They for instance recognize that "the United States Constitution, ordinarily venerated as a safeguard of our liberties, would do little in practice to protect us" from the kind of problems they study in the book (239). The US Constitution -in their view- seems old and rigid (very difficult to change), and its structures unprepared to deal with the challenges posed by the new forms of authoritarianism that the book explores. Worse still, the difficulty posed by the "absence of legal safeguards" is -they claim- "coupled with the difficulty of pro-democracy mobilization" (243). 
"the risk of slow, but ultimately substantial unraveling along the margins of rule-of-law, democratic, and liberal rights" (39). "Democratic erosion" would imply a "process of incremental but ultimately still substantial, decay in the three basic predicates of democracy -competitive elections, liberal rights to speech and association and the rule of law, across different institutions, against a baseline of some ingoing level of democracy" (43-4). Years ago, the emergency powers and military coups were important to "fast democratic breakdowns," which usually yielded to "a clearly authoritarian form of government." In contrast, the "slow erosion" of democracy would constitute the more common phenomenon of our time -a phenomenon that usually ends up with "some kind of competitive authoritarian structure" (39). Summarizing a central part of their approach, they state: "In the last decade of the twentieth century, liberal democracy seemed to have triumphed everywhere. Yet today there is increasing concern that the form of democracy provides a façade for undemocratic behavior" (9).

In the face of the threats posed by these growingly common situations of democratic backsliding, Ginsburg and Huq want to "consider whether law, and in particular the constitutional law that structures the basic institutions of government, can mitigate such risks (3). For that reason, they accompany their remarkable comparative analysis with the study of numerous possible institutional changes, which promise to make constitutional democracies more solid and stable. Among the many mechanisms and changes that they explore, we find suggestions as varied as the following: a more "careful and thorough articulation of [basic democratic] rights" in the Constitution (198); the establishment of "independent election bodies", "nonpartisan electoral commission" (199) and "effective supervision of electoral processes and guarding against corruption" (as it was done in Mexico in recent years); the use of a legislative "supermajoritarian escalator" provision for the authorization of emergency powers (like the one recently suggested by Bruce Ackerman) (201); the augmentation of legal protections of bureaucratic autonomy (225); or the use of ombudsman-like officers in charge of identifying fraud and abuses of power (225)

\section{A CRITICAL ANALYSIS}

In what follows, I want to critically engage with some of the main claims and ideas that appear in Ginsburg and Huq's book. Recognizing the value and strength of their work, I aim in this way to contribute to the important conversation they advanced concerning the gradual decay of our liberal constitutional democracies. Consequently, in the next pages I will briefly examine a few of the many interesting issues examined in their book.

American exceptionalism? I want to begin this critical analysis with a rather minor point, which may give an idea of the kind of difficulties that I 
find in their book. In the introduction of How to Save a Constitutional Democracy, the authors "reject claims of American exceptionalism" $(4,234)$ making it explicit that they do not want their analysis to be affected by that bias. However, it seems to me that their work is still very much affected by the problem of "American exceptionalism" that they wanted to avoid. Let me mention one important manifestation of this bias, which I find in How to Save... In their study, Ginsburg \& Huq address the problem of "democratic erosion" and treat it as a rather novel phenomenon. But the fact is that the "democracy-erosion" difficulty refers to a rather old problem, and not one that just became apparent after the election of Donald Trump. The issue of "democratic erosion" refers to a well-known difficulty that has been affecting numerous countries, since the very origins of constitutionalism. Think, for instance, about the vast majority of Latin American countries that, at least since the mid-19 $9^{\text {th }}$ Century, adopted (what I called) an "unbalanced system of checks and balances" in their Constitutions. Latin Americans built this inadequate institutional structure by mixing the US model of "checks and balances" with the system of concentrated Executive (or monarchical) authority, which had prevailed in the region during the years of Spanish colonization. That Latin American version of the system of "checks and balances" modified the original US model in a dramatic way, because in the latter the different branches were endowed with relatively equal powers while, in Latin America, the Executive branch was from the start designed as a much more powerful branch -in relative terms- than the others. This situation generated that, from the very first minute of its adoption, the Latin American system of "checks and balances" became intrinsically "unbalanced." As a consequence, the President began to gain gradual control upon the rest of the branches, thus undermining the efficiency, legitimacy and quality of Latin American's democratic governments. The problem of "democratic erosion" became thus a central part of Latin American constitutioanlsim at least since the mid-1850s. This would then be my first claim: in spite of their efforts, Ginsburg and Huq seem to be assuming an approach very much affected by the bias of "American exceptionalism" that they had eagerly tried to avoid. As a result, they tend to talk about democracy's decay and the problem of "democratic erosion" as if all these difficulties had surprisingly emerged after Donald Trump's election.

Diagnosis. A more significant problem has to do with Ginsburg and Huq's diagnosis of the problem addressed in their work. In my view, How to Save... conflates two different issues, which should have been the object of a different, separate examination. Thus, in their analysis of the causes contributing to the erosion of liberal constitutional democracy, the authors put together problems that have to do with the realm of constitutionalism (problems related to the establishment of limits upon power) and problems related with the realm of democracy (i.e., the decay in popular commitment to democracy). 
They overlap these two "causes" as if they necessarily worked together, or as if they implied in the end one and the same thing. But the fact is that the difficulties that affect contemporary constitutionalism, and those that affect democracy in our time, are very different in nature and require separate attention. Imagine, for instance, that we -somehow miraculously- managed to restore the old machinery of "checks and balances. Imagine that we put an end to the extended practice of Executive's abuses; that we finally limit the dismantling of all the existing controlling devices, etc. Now, even if we magically achieved those ambitious goals, a central part of our "democracyerosion"-problem would still be in its place, fundamentally untouched. For one thing, people would continue to feel alienated from power and disengaged from democracy. And this would be so because the problems posed by the crisis of constitutionalism significantly differ from those posed by the crisis of democracy. In other words, people do not feel politically alienated because, say, judges are not checking the Executive; legislators are too deferent towards the President; or the Executive is not properly controlled. "We the People" feel distanced from politics because they have still very few chances to meaningfully participate in politics.

Democratic dissonance. In page 34 of their book, Ginsburg and Huq make clear that they will not study the "root causes" of the problem of "democratic erosion", but rather address other, more "tractable" and "mundane" questions. More specifically, the authors concentrate their attention on what could be done through institutions in order to confront the problem of "democratic erosion". This methodological choice seems perfectly reasonable: they want to focus their analysis on a "mid-level" ground, which is neither too abstract, nor too close to the political conjuncture. However, and given the particular approach that they take in their book, my proposal to the authors would be to put more attention on a (root) problem, intimately related to the constitutional structure that they have selected as a (or the) crucial axis of their analysis. The problem I am thinking about is one that -I believe- goes to the heart of the explanation about the present democratic crisis. I call this the problem of "democratic dissonance".

To explain this "dissonance" I would refer to two facts. In the first place I would mention i) the fact that many modern Constitutions have been written under the guidance of an elitist paradigm (which means that those who were in charge of writing the Constitution shared fundamentally elitist assumptions); and then ii) the fact that the Constitutions that incorporated those elitist assumptions operate at the present time under a completely opposite paradigm, characterized by a shared feeling of "democratic empowerment". Presently, I assume, "We the People" consider that they have the right to be consulted about all those public decisions that affect them directly. This situation -I submit- creates a severe "dissonance" between, on the one hand, the possibilities that are open to "We the People" by the prevailing 
institutional system and, on the other hand, the demands and expectations that that same people have in relation to democracy and democratic institutions. If the authors had taken such a problem -the problem of "democratic dissonance"- more seriously, they would have then be inclined to encourage, rather than resist or ignore, the adoption of institutional solutions directed at favoring democratic participation and decision-making (I shall come back to this point later).

The fact that Ginsburg and Huq do not address the problem of constitutional elitism and its consequences more directly is also strange, given that they recognize the presence of this difficulty and some of its main implications. See, for instance, their references to David Van Reybrouck's timely book Against Elections -a book that Ginsburg and Huq quote with emphatic approval. In that work, Professor Van Rybrouck highlights a paradox of our time, according to which people simultaneously express a growing interest in politics and manifest a growing dissatisfaction with professional politics - or, to put it somehow differently: nowadays, the people both express an increasing engagement with democracy and political participation, and manifest an increasing disenchantment with existing democratic systems (202-3). This seeming paradox fits very well with what I called the problem of "democratic dissonance". The existence of this "democratic dissonance" helps us to properly understand those seemingly contradictory facts, namely the people's high democratic aspirations and their disengagement or even anger towards our dominant institutional practices.

In addition, Ginsburg and Huq seem to agree with my previous analysis in what regards the elitist, non-democratic origins of the (US) Constitution (see, for instance, 16). However, this initial agreement seems to be shortliving. In their book, the authors appear to be saying that either those elitist influences were merely rhetorical (or in some other way innocuous), or that such elitist background became somehow dissolved after some time (16). Their idea seems to be that, in the end, the democratic ideal found its way and became pretty much realized, at least during long decades. I reject this view, however, because I believe that those original, elitist assumptions that guided our "founding fathers" became deeply ingrained in the basic constitutional structures that they then constructed -constitutional structures that are still very much with us. This situation (the persistence of elitist institutional arrangements), has been aptly described by Professor Roberto Unger when he wrote about the "dirty little secret" of our constitutional system. This "dirty little secret" has to do with a "discomfort with democracy," which would for instance be reflected -according to Unger- in the "ceaseless identification of restraints upon majority rule", the "hypertrophy of countermajoritarian practices and arrangements"; etc. (UNGER 1996, 72-3, 115). An alternative, more critical point of departure (as the one presented by Roberto Unger), would have induced the authors to modify their diagnosis and would have 
also motivated them to adopt a different approach in the search for structural changes and institutional alternatives (see below).

Reinvigorating democracy. Another problem that I find in the book relates to the authors' views about the decay of "popular commitment" to democracy -and its cure. In many passages of the book, Ginsburg and Huq refer to the importance of having a citizenry that is committed to democracy, and also mention the serious problem that emerges when people begin to distance themselves from politics. They write about the "decay in popular commitment to democracy" (245); and also about the importance that "cultivating" citizens' participation (203). They state: "there is a large question now of how prosocial and prodemocratic values can be cultivated or reinvigorated across the political aisle" (244). Moreover, the authors frequently refer to the value of "political morality" and maintain that "[d]emocracy demands from its participants a certain political morality" (173). Remarkably, however (and in spite of the efforts they always make to provide empirical support to their claims), they conclude, with no additional premises, that "[i]n the absence of that political morality, nothing in the toolkit of constitutional designers will save constitutional democracy. Design, in short, can go only so far without decency" (ibid.). More significantly, in a crucial paragraph of the book, they state:

There is no democracy without a decent measure of popular commitment to democracy. Maintaining that commitment depends on what people continue to want in terms of a government, in terms of a country for themselves and their children. It is a matter of beliefs and preferences, not incentives or stratagems, which are transmitted within families, schools, churches, mosques, synagogues, workplaces, and social media networks. Without those beliefs, without a simple desire for democracy on the part of the many, the best institutional and constitutional design in the world will likely be for naught. (244, italics added).

I find most of these claims deeply problematic. Contrary to what Ginsburg and Huq write, I believe that popular commitment to democracy is much less "a matter of beliefs and preferences" than a product of "incentives or stratagems". To recognize why, we need to first understand how much political apathy is an endogenous product of the prevailing institutional system. This claim is obviously connected to what I stated before, namely that the elitist constitutional system that was put in place at the end of the $18^{\text {th }}$ Century is still with us. The reforms that such constitutional system received, in the last two Centuries (particularly in Europe and Latin America), were mainly directed at expanding the declaration of rights, which means that the structure of powers that was then organized has not been substantially changed. In other words, in spite of the gradual expansion we have seen in constitutional declaration of rights, the old $-18^{\text {th }}$ Century- organization of powers has been 
kept fundamentally untouched (see, in particular, GARGARELla 2010). As a result of this, we still pretty much have a "counter-majoritarian" institutional system that is based on certain hostility towards democracy, which prevents, rather than promotes, popular participation in politics. This is why, for those who want to foster political and legal change, the strategy of doing lobby results much more convenient or reasonable than that of promoting massive political mobilization: one lobbyist situated in the right place at the right time may gain much more than the mobilization of millions during months. When people understand this -and I think that they understand this pretty soonthen they reasonably refrain from using their political energies to mobilize for change. But then -we have to admit- their seemingly "passive" attitude towards politics should not anymore be considered the product of their "beliefs and preferences," but rather the consequence of the lack of institutional opportunities that they find (say, the resistance that public authorities establish against their claims; or the level of repression they suffer; etc.).

A Schumpeterian approach to democracy. Many of the problems that appear in Ginsburg and Huq's book -problems as the ones presented in previous paragraphs- seem to derive from the minimalist, restrictive, approach to democracy" that the authors unnecessarily endorse in their work (14, also 10). In fact, Ginsburg and Huq take as the baseline for their analysis a Schumpeterian understanding of democracy -"a thin Schumpeterian concept of democracy"-according to which democracy is described as an "institutional arrangement for arriving at political decisions in which individuals acquire the power to decide by means of a competitive struggle for the people's vote" (8).

The authors may say, in defense of this minimalist assumption about democracy, that they wanted to be able to describe and compare very different institutional systems across the world. This would explain why they chose such a thin concept of democracy: this definition would allow them to "capture" the widest variety of existing democratic regimes. In other words, they would not want to exclude from their comparative analysis, say, a certain "modest" or ill-functioning democracy, simply because it does not comply with the sophisticated standards established by their preferred, robust ideal of democracy.

I would resist, however, this approach to democracy, both at a descriptive and at a normative level. In the first place, the Schumpeterian approach seems not only minimalistic, but also particularly unattractive. It is unattractive, in particular, because the strong bias it incorporates against political participation: participation appears, for this view, limited to the act of voting (Ginsburg and Huq seem to be satisfied, more than concerned with the fact that "electoral mobilization remains the primary and most important channel of public participation in the United States and other democracies" [244]). Moreover, according to this view, the stability of democracy depends on the existence of widespread apathy and general political incompetence. 
But: why should our definition of democracy be so resistant to the value of political participation? And, again: is political apathy a common or baseline characteristic of most modern democracies? Should it be considered as such?

All the previous considerations help us recognize that the Schumpeterian approach does not merely express a descriptive conception of democracy, but also includes -against what it proclaims-strong normative components, which should also be considered a problem for this view. Moreover, and in connection with this mixture of descriptive and normative components, I would suggest that what the minimalist approach "captures" is compensated by what it misses or gets wrong. More precisely, the minimalist approach induces us to describe as "normal" or "paradigmatic" democratic systems, systems that -perhaps- we had not reason to consider as such - say, democracies where social protests are usually repressed; popular participation discouraged; and political decisions mainly reserved to "enlightened" elites. Such democratic systems would be better described as "weak" or "restrictive" democracies, rather than as "normal" or "paradigmatic" ones. To put it differently: we should not take as our measure of democracy what in the end is a questionable "construct" -the product of successive elitist and exclusive governments, and heavily counter-majoritarian Constitutions.

Rights. What I just said about democracy could also be said about how the authors deal with the notion of constitutional rights. In fact, Ginsburg and Huq unnecessarily and unjustifiably subscribe a too thin notion of rights. They maintain, for instance, that their approach to democracy only focuses on "a core of 'first generation' rights of speech, assembly, and association". This is to say, in their study, they adopt a (hyper) minimalist approach to rights, which does not (even) consider all "liberal" or "first generation" rights, but only those that favor political competition/ rights against the state (11). This reductive approach to rights is controversial for reasons that are similar to the ones that were just mentioned, in the previous analysis of the concept of democracy. But now I would also like to underline an additional problem, which in the case of constitutional rights becomes more salient and manifest. The problem I am thinking about has to do with the bias of "American exceptionalism" that Ginsburg and Huq wanted to avoid. What their approach to rights makes clear is that -in spite of their claims to the contrary- the authors' analysis is still very much fixed with the US model, which is still taken as the baseline Constitution against which all the other Constitutions are then compared. In fact, the US Constitution is one of the very few in the world that does not include, within its declaration of rights, a broad and robust list of social, economic, human, cultural and multicultural rights -like, for instance, many European Constitutions and most Latin American Constitutions do.

New mechanisms for inclusive discussion. The last point that I want to make also relates to the weak conception of democracy that Ginsburg and Huq 
take as the baseline for their analysis. By having such as restrictive view as their point of departure, all the proposals they present, and all their analysis of possible alternatives as well, tend to be biased in a quite conservative way. For instance, at one point of their study, the authors begin to imagine alternative constitutional choices that would be able to confront or limit the evil of "democratic erosion" (167). One could have expected them to propose the adoption of mechanisms and incentives directed at re-igniting the democratic engine, as Jurgen Habermas, for instance, could have suggested. The authors could have suggested, for that matter, the adoption of different institutional alternatives: from very modest incentives, like mandatory voting, to more ambitious reforms, like the making of popular consultations obligatory regarding certain matters (i.e., as the ILO Convention 169 does for the protection of aboriginal rights).

However, the authors' weak conception of democracy moves them to propose-expectedly-only very modest reform proposals. More worrisome still, the authors adopt a quite skeptic attitude in relation to the new experiences of inclusive deliberation and citizens' assemblies that have emerged all around the world in recent years. I am thinking, for instance, about the 1998 Australian Assembly that -notably- was composed of by professional politicians and regular citizens; the participatory assemblies of British Columbia 2005 and Ontario 2006, which organized citizens' conventions (whose members were selected by lot) aimed at discussing and proposing new electoral systems; the deliberative experience developed in the Dutch Citizen Forum in 2006; the "crowdsourcing" Constitutional Convention of Iceland (2009-2013); the deliberative assemblies of Ireland 2012 and 2016 (that were also composed of by members elected through lottery), which ended with two successful referenda, one on gay marriage and the other on abortion.

All those experiences with inclusive and deliberative assemblies were of extraordinary importance. Among other things, they helped us to debunk some of the most controversial and influential assumptions of our time, like those suggesting i) that people are not motivated to participate in politics (when people usually are, particularly when the issue under discussion is a matter of their interest, and they recognize that their opinions are going to be taken seriously); ii) that regular citizens are not prepared to discuss about complex issues -like abortion, equal marriage or electoral systems (when they can perfectly be, as far as the process is organized in ways favorable to civic education); iii) that divided societies cannot properly discuss about divisive issues or issues where the people's identity or religion is at stake (while, by contrast, we have recently confirmed that even in very Catholic countries like Ireland or Argentina, the people can discuss and change their views on matters such as abortion or equal marriage).

Now, against all these remarkable experiences, Ginsburg and Huq assume a very skeptical approach. In the best case, they ask defenders of these views 
to demonstrate that such assemblies can also work in large scale experiments (203-4). Taking -again- the US experience as the metric against what everything else needs to be measured, they claim that "we have no evidence yet that mechanisms of sortition or citizen-led deliberation can work on the scale of a large country like the United States" (204). Their demand, I think, is somehow unfair, given what we already know and what we have already learnt from them, namely that those deliberative experiences functioned pretty well in very different contexts and before the most difficult questions. In fact, they seemed to properly work in the case of large countries (like Ireland and Australia); with regard to difficult and technical issues (electoral systems); concerning questions where identity or religion were involved (abortion, gay marriage); and even in the context of divided and polarized countries (Ireland, Argentina). Having a more robust conception of democracy as their normative standpoint would have helped the authors to welcome, rather than resist or quickly dismiss, those promising alternatives: the cause of democracy -I believe- require us to fight for them.

\section{REFERENCES}

Bermeo, N. Democracy Backsliding. In Journal of Democracy. Vol. 27, Nr. 1, January, 2016, 5-19.

Dixon, R. How to Save a Democracy? In Jotwell. 2018. Available at: https://www.law. uchicago.edu/news/ginsburg-and-huqs-how-save-constitutional-democracy-reviewedone-absolute-best

Gargarella, R. Latin American Constitutionalism, 1810-2010. Oxford: Oxford University Press, 2013.

Ginsburg, T. \& HuQ, A. How to Save a Constitutional Democracy. Chicago: The University of Chicago Press. 2018.

Graber, M.; Levinson, S. \& Tushnet, M. (eds.). Constitutional Democracy in Crisis? Oxford: Oxford University Press, 2018.

Landau, D. Abusive Constitutionalism. In UC Davis Law Review 47, 189, 2013.

Levitsky, S. \& Ziblatt, D. How Democracies Die. New York: Crown, 2018.

Luo, Z. \& Przeworski, A. "Subversion by Stealth: Dynamics of Democratic Backsliding". 2019. Manuscript in file with the author.

Sunstein, C. (ed.). Can it Happen Here? Authoritarianism in America. New York: Library of Congress, 2018.

Unger, R. What Should Legal Analysis Become? London: Verso Books, 1996. 